\title{
MANAGEMENT OF THE BLUNT PEDIATRIC CERVICAL TRAUMA - CHALLENGE FOR THE TRAUMA SURGEON AND THE OPTIONS OF SOLVING THEIR EMERGENCY CONDITIONS (A CASE REPORT)
}

\author{
University Hospital of Trauma, \\ National Trauma Center ${ }^{1}$, Tirana, Albania, \\ St. Mary's Hospital ${ }^{2}$, Vechta, Germany \\ Klinkum rechts der Isar ${ }^{3}$, Munich, Germany
}

Тупые травмы шеи не являются редкостью в травматологической практике. Как правило, они связаны, либо с прямыми травмами шеи, либо травмами типа «ускорение-замедление». Такие травмы обычно сопровождаются сопутствующими повреждениями шейных структур. Этот особый тип травмы, представляющий особые трудности, как для врачей скорой помощи, так и анестезиологов и хирургов. Мы описываем случай травмы трахеи в результате тупой травмы грудной клетки, с которым хирурги успешно справились.

Мальчик (12 лет) упал с велосипеда и получил тупую травму груди. Он был доставлен в больницу (через 6 ч) с болью в груди и затруднением дыхания, а также с неспособностью говорить. Частота сердечных сокрашений (ЧС) была 120 в 1 мин, систолическое артериальное давление (САД) - 110-70 мм рт.ст., частота дыхания (ЧД) - 32 в мин. и $\mathrm{SaO}_{2}-90 \%$. Случай представлял клинический интерес по поводу нарастающей подкожной эмфиземы, простирающейся от верхней части грудной клетки до шеи и головы. Рентгенограммы и КТ показали правосторонний пневмоторакс, пневмомедиастинум и девиацию трахеи. Пациент по экстренным показаниям был доставлен в операционную, где ему установили дренаж в правую плевральную полость. При фиброскопии трахеи выявилось, что полученная травма находилась 2-3 см ниже продольного направления (около 1 см) в передней мембранной части трахеи, где и произошел разрыв. Во время процедуры состояние ребенка ухудшилось (падение $\mathrm{SaO}_{2}$ до $86 \%$ и затруднение дыхания), но гемодинамические показатели оставались стабильными. В этих условиях, потребовавших экстренного вмешательства, была выполнена трахеотомия. Сразу все параметры нормализовались. На следующее утро клинические симптомы оставались без изменения и за весь период госпитализации осложнений не наблюдались. Пациент был выписан домой через несколько дней.

Травмы трахеи являются редким осложнением тупой травмы груди. У пациентов, как правило, присутствуют признаками дыхательной недостаточности. Первичное восстановление является лечением выбора в случае наличия больших дефектов, в то время как лечение небольших разрывов можно проводить консервативно. Для восстановления ухудшающейся легочной функции рекомендуется выполнение экстренной операции.

Ключевые слова: тупая травма груди, подкожная эмфизема, трахея

Blunt injuries to the chest are not rare but if present are usually associated with either a direct impact to chest and neck or acceleration-deceleration injuries. Such injuries are associated with concomitant injuries to the cervical structures. This particular type of injury thus presents a diagnostic and therapeutic challenge to emergency physicians, anesthetists and surgeons alike. We report a case of tracheal injury due to blunt upper thoracic trauma which surgeons have successfully coped.

A 12-year-old boy fell from bicycle and sustained blunt injury to his upper chest aperture. He was brought to the hospital (6 h later) with pain in the chest, difficulty in breathing and inability to speak. His heart rate (HF) was $120 / \mathrm{min}$, systolic blood pressure (SBP) was $110 / 70 \mathrm{~mm} \mathrm{Hg}$, respiratory rate (RR) was $32 / \mathrm{min}$ and $\mathrm{SaO}_{2}$ was $90 \%$. This case is interesting in subcutaneous emphysema extending from his upper chest to his head, covering neck and throat. Radiographs and CT scan revealed a right-sided pneumothorax, pneumomediastinum and tracheal deviation. The patient was emergently taken to the operating room and a right-chest tube was placed. The patient underwent fiber optic examination of the trachea, where a injury $2-3 \mathrm{~cm}$ below of longitudinal direction $(1 \mathrm{~cm})$ in the anterior membranous part of the trachea has been detected, thus formally the trachea was ruptured. During the procedure the child's condition deteriorated with diminishing $\mathrm{SaO}_{2}$ down to $86 \%$ and difficulty in breathing but the child was hemodynamically stable. Under these conditions emergency intervention tracheotomy has been performed. Immediately all respiratory parameters returned to normal. The next morning the symptoms and signs were normal with no further complications. The patient was discharged home after a few days. Tracheal injury is a rare complication of blunt chest trauma. The patients usually present with symptoms and signs of respiratory distress. Primary repair is the treatment of choice in case of large defects, while small tears can be managed conservatively. Immediate operation is recommended to improve deteriorating pulmonary function.

Keywords: blunt chest trauma, subcutaneous emphysema, trachea rupture, pediatric, neck trauma, bicycle 
Novosti Khirurgii. 2014 Jul-Aug; Vol 22 (4): 488-491

Management of the blunt pediatric cervical trauma - challenge

for the trauma surgeon and the options of solving their emergency conditions

S.A. Dogjani, E.B. Hasanaj, E. Matevossian, D. Doll

\section{Introduction}

Tracheal injuries are uncommon but potentially fatal, while the incidence of tracheobronchial injury is reported to involve in $4 \%$ of all cases of thoracic trauma [1]. Postoperative mortality rate is reported to be up to $59 \%$ of cases after tracheobronchial rupture in motor vehicle accidents (MVA), but these patients often have associated with multi-organ trauma [2, 3]. Despite on the rarity, tracheobronchial damages can always be found behind closed chest trauma and can sometimes be detected with a high degree of suspicion. Its treatment should start early, solve airway and respiratory problems and avoid mediastinitis using antibiotic cover [4].

Blunt cervical trauma is not commonly a single organ trauma, and it is generally associated with other injuries to associated surrounding anatomical structures such as bone, muscle or neurovascular bundle, due to the mechanism of injury, force and angle, as well as the status of tissues (age of the patient). Tracheal injury can be found associated to closed blunt thoracic trauma, and can be present as damage to the tracheobronchial tree damages above and below the carina. Such injuries are a challenge in diagnostics and treatment to emergency physician, trauma surgeon or anesthetists.

In this article we present one of the rare cases with blunt damage to the pediatric trachea, and describe treatment strategies in the management of blunt injuries of the cervical trachea at its level. We are convinced that this demonstration is as rare as it is interesting to the interested reader and will serve to deal with this type of trauma, and highlight the potential problems it carries with its' diagnosis.

\section{A case report}

A 12-year-old boy from a town $100 \mathrm{~km}$ from Tirana fell from and onto his bicycle, causing injury to the cervical region and a closed upper chest aperture trauma. After receiving first aid he was brought to the district hospital in hemodynamically stable conditions, but with symptoms and signs of subcutaneous emphysema in the cervical region. Emphysema had increased progressively as did the hoarseness of voice during the last 6 hours, and so the patient was transported to our hospital for further specialized treatment. Immediately on arrival we initiated assessment and diagnosis according to the world wide known Emergency Department treatment protocols of Advanced Trauma Life Support (ATLS). We concluded that the patient had difficulty in respiration and breathing $(\mathrm{A}+\mathrm{B}$ problem) and was unable to speak, with tachycardia $(120 / \mathrm{min})$, tachypnea $(32 / \mathrm{min})$ in combination with a reduction of saturation $\left(\mathrm{SaO}_{2}-90 \%\right)$.

It is worth mentioning that as the patient received any stress, no matter how small, this was accompanied with further enlargement of the emphysema in this neck region, which worsened the respiratory condition of the patient. On arrival, he was kept on continuous oxygenation mask, which kept the $\mathrm{SaO}_{2}$ in acceptable range without further deterioration. On clinical examination we found a subcutaneous emphysema which stretched from the upper thorax aperture upwards towards the head including neck in the front and lateral (fig. 1). It was found that he had a bruising at the cervical region that coincided with the level of impact of the bicycle, which measured $5 \times 10 \mathrm{~cm}$ and had a darkened area in the center. While continuing intensive care monitoring was given, treatment procedures were initiated. Respiration rate and saturation were uneventful thus far, and so chest X-Ray was done, proving a small right sided pneumothorax, with engorging pneumomediastinum and shift of the trachea to the right side (fig. 2).

Immediately the patient was sent to the operating room and a intercostal drainage was placed at the right side. With installation of the drainage, the boy's condition improved, and the enlargement of the subcutaneous emphysema diminished.

Following IC drain insertion we proceeded with further examination to precisely identify the level of the damage to the trachea through flexible bronchoscopy, which indicated that the damage was $2-3 \mathrm{~cm}$ below the larynx and in longitudinal direction. The membranous portion of the trachea

\section{Fig. 1. Neck exam reveals regional bruising}

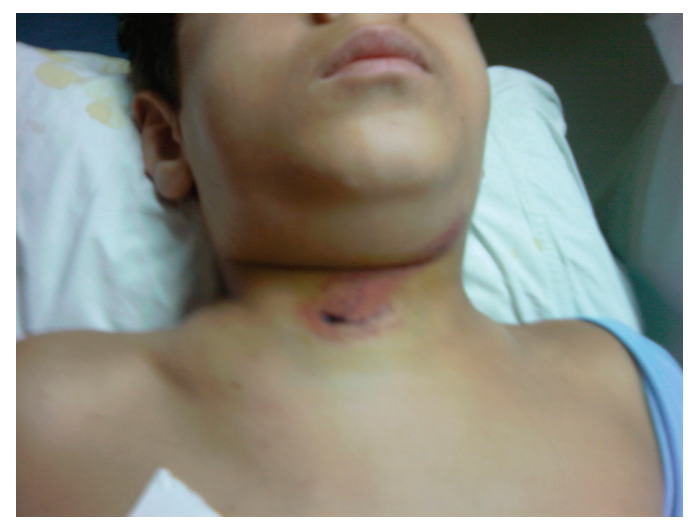




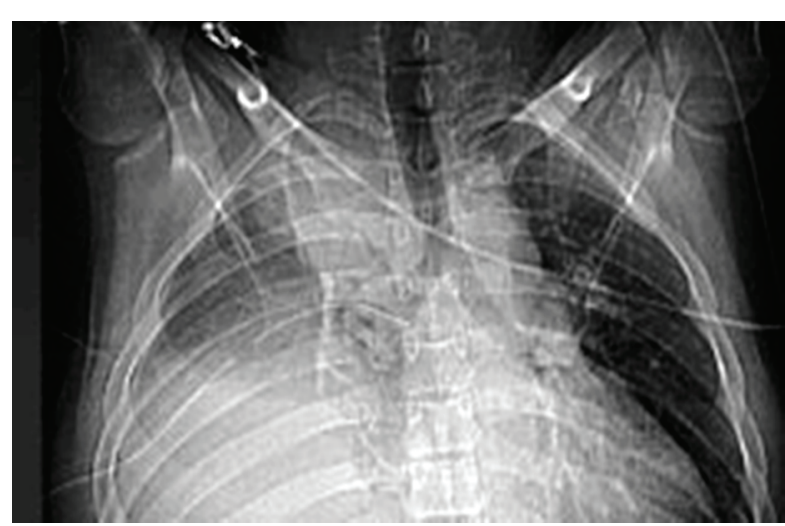

Fig. 2. Chest X-ray, showing pneumomediastine and deviation of the upper trachea at the chest aperture to the right

was ruptured at about $1 \mathrm{~cm}$ length.

During the procedure of bronchoscopy the oxygenation decreased and the patient showed difficulty with breathing, even if bronchoscope was removed. The intercostal drain was proved working. In this situation we identified the need for an emergency surgical procedure, and we performed tracheotomy. This was not without difficulties as the incision had to traverse the already under bronchoscopy increased subcutaneous emphyse$\mathrm{ma}$ at the anterior neck region. With institution of successful tracheotomy and insertion of a tracheal cannula immediately all parameters were improved and the level of oxygenation and respiration returned to normal, as did the respiratory efforts. The patient was held for 24 hours in the intensive care unit (ICU) to monitor all vital parameters. In the next morning the child's condition was uneventful and without any complication. Five days after the chest drain was removed the patient only had dressing treatment to his trachea cannula and was discharged. The cannula was removed uneventfully after 2 weeks and left to close.

\section{Discussion}

Laceration of the trachea is a very rare injury after blunt trauma, including the laceration of full or partial perforation of the trachea or bronchial wall.

Tracheal injuries occur in $0,4-1,5 \%$ of patients with trauma and can be found occult in 2.8$5.4 \%$ of trauma at autopsy. Tracheobronchial injuries have been reported in $18 \%$ of autopsies after emergency intubation.

However, it has been observed previously that even light trauma may initiate occult damage, thus the real incidence of tracheal damage actually is higher than reported. Major if not bony trauma is to be anticipated, if the posterior portion of the trachea is injured. It is not only eminent for injuries to the anterior wall of the trachea that these are rarely isolated injuries, but often come along with a com- bination trauma to the surrounding structures and consecutive damage and swellings [5]. This may lead to temporary airway occlusion as was the case in our patient during bronchoscopy.

In two-thirds of the survivors of blunt neck trauma, there are delays in diagnosis of tracheal or trachea-bronchial injuries, especially if no obvious emphysema or pneumothoraxes are present. Complications may be respiratory compromise, tracheal fracture and collapse, laryngeal trauma and lung complications as contusion, atelectasis, pneumonia, mediastinitis, sepsis and long term decreased lung capacity [5]. It may be suspected that women and children may need endotracheal intubation earlier because their trachea is smaller [6], but neck injuries may generally need early intubation due to fast neck swelling with airway compromise.

Injuries of the anterior part of the trachea are usually the result of penetrating traumatic injuries; blunt injuries are seen less often. The strong cartilaginous structure of the proximal trachea and bronchi is fixed with ligaments, while the distal bronchi and lungs are more mobile. Thus this transitional zone is more vulnerable to deceleration injuries, and injuries from trauma usually occur at the transition zone between the fixed and the mobile bronchi within $2-5 \mathrm{~cm}$ above the carina [7]. Clinical signs of damage to the trachea may be as follows: dyspnea, cough, haemoptysis, cyanosis, cervical subcutaneous emphysema, tracheal deviation and mediastinal emphysema, signs of the airways obstruction.

CT-scanning is highly preferred, when injury mechanism or clinical presentation lead to the suspicion of tracheobronchial damage. A multiplanar reconstruction of the entire tracheobronchial tree can aid establishing the diagnosis $[8,9]$.

Flexible, or Fibrobronchoscopy (FBS) is an invasive diagnostic method that enables the exploration of all possible tracheobronchial tree injuries. While an a.p. chest X-ray may suggest respiratory damage in terms of contusion or atelectasis, FBS is recommended to identify damages to the tracheobronchial tree. In the most severely injured patients, this is an excellent and fast tool to diagnose the major injury site and the extent of alteration of the tracheobronchial tree anatomy. FBS is now mostly available in larger and mid-size hospitals. Vascular lesions (intimal lesions) of neck vessels may arise in the arteries following blunt trauma, but are seldom in pediatric patients. The fastest and most reliable tool in terms of diagnostics is an Angio-CT examination of the aortic arch and appended neck arteries.

The presence of pneumomediastinum / pneumothorax may parallel the extent of injuries to the tracheobronchial tree, but there is no reliable corre- 
lation in between. The discovery of pneumothorax needs IC drain therapy. Routine chest X-Rays are important to estimate whether pneumomediastinum / pneumothorax is still present or in progress.

In our patient, saturation drop lead to tracheotomy and cannula insertion, which was done swiftly. Tracheotomy was done and not cricothyroidotomy, as the patient was already in theatre, so an emergency cricothyroidotomy (which has to be converted into a definitive stoma anywhen later) could be avoided. The tracheal cannulation was clinically not needed any more after one day, as neck swelling subsided, but we kept it in place for 2 weeks for reasons of patient safety, after which it was removed and left for spontaneous closure under dressing. The tracheal tear injury was decided it would not profit from suturing, and as it was small, it was left for primary healing. The patients did not show up for follow up, which should have controlled for tracheomalazia and tracheal stenosis. We cannot report on the outcome of this pediatric blunt tracheal injury though.

\section{Conclusion}

Blunt tracheal trauma are rare injuries that require surgical intervention in almost all cases [5]. Small lacerations can be managed non-operatively, while large tears requiring the definitive surgical treatment, which in $90 \%$ of cases may have a good outcome without early and late complications [10, 11]. The natural history of these lacerations can cause complications such with severe scarring and ultimately stenosis of the trachea. If operated on, early extubation of these patients is of benefit.

\section{Parental consent was obtained to demonstrate this clinical case.}

\section{REFERENCES}

1. Symbas P. N. Rupture of the airways from blunt trauma: treatment of complex injuries / P. N. Symbas, A.
G. Justicz, R. R. Ricketts // Ann Thorac Surg. - 1992 Jul. - Vol. 54, N 1. - P. 177-83.

2. Iatrogenic ruptures of the tracheobronchial tree $/ \mathrm{H}$.

S. Hofmann [et al.] // Eur J Cardiothorac Surg. - 2002 Apr. - Vol. 21, N 4. - P. 649-52.

3. Kiser A. C. Blunt tracheobronchial injury: treatment and outcomes / A. C. Kiser, S. M. O'Brien, F. C. Dettebeck // Ann Thorac Surg. - 2001 Jun. - Vol. 71, N 6. - P. 2059-65.

4. Sung H. M. Tracheal tear during laryngo-pharyngectomy and transhiatal oesophagectomy: a case report / H. M. Sung, B. Nelen // Can J Anaesth. - 1989 May. - Vol. 36, N 3. - Pt. 1. - P. 333-35.

5. Tracheal or bronchial rupture / P. Armstrong [et al.] // Imaging of diseases of the chest / eds. P. Armstrong [et al.]. - 3rd ed. - Mosby-Year Book, 2000. - P. 95860, 977-81.

6. Collins J. CT of nonpenetrating chest trauma / J. Collins, S. L Primack // Appl Radiol. - 2001. - Vol. 30, N 2. - P. 11-21.

7. Fraser R. S. Fraser and Pare's diagnosis of diseases of the chest : 4-volume set / R. S. Fraser, N. L. Muller, N. C. Colman. -4 th ed. - Hardcover, WB Saunders Co, 1999. $-3500 \mathrm{p}$.

8. Freiberger J. An unusual presentation of an airway tear / J. Freiberger // Anesthesiology. - 1984 Aug. Vol. 61, N 2. - P. 204-6.

9. Barmada H. Tracheobronchial injury in blunt and penetrating chest trauma / H. Barmada, J. R. Gibbons // Chest. - 1994 Jul. - Vol. 106, N 1. - P. 74-78.

10. Surgical approaches to membranous tracheal wall lacerations / A. Mussi [et al.] // J Thorac Cardiovasc Surg. - 2000 Jul. - Vol. 120, N 1. - P. 115-18.

11. Tracheal and main bronchial disruptions after blunt chest trauma: presentation and management / F. Baumgartner [et al.] // Ann Thorac Surg. - 1990 Oct. - Vol. 50, N 4. - P. 569-74.

Адрес для корреспонденции

Department of Surgery,

St. Mary's Hospital Vechta,

Marienstr. 6-8, D-49377

Vechta, Germany, Europe

Cell +49 172358 5454;

Fax: +49 444199 1250;

e-mail: ddoll@gmx.de

PD Dr. Dietrich Doll, MD, PhD.

\section{Сведения об авторах}

Dogjani S.A. MD, PhD, General Surgeon at the University Hospital of Trauma, National Trauma Center, Tirana, Albania

Hasanaj E.B. MD, General Surgeon at the University Hospital of Trauma, National Trauma Center, Tirana,
Albania

Matevossian E. MD, PhD, Klinkum rechts der Isar, Munich, Germany

Dietrich Doll, MD, PhD. Priv-Doz. Dr. Department of Surgery, St. Marys Hospital Vechta, Germany. 